\title{
International Mechanism of the Environmental Information Access and Cooperation Framework for Climate Change Protection
}

\author{
Viktor Ladychenko ${ }^{1}$, Olha Melnychuk ${ }^{2}$, Olena Yara $^{3}$ and Julia Kanaryk ${ }^{4}$
}

\begin{abstract}
Climate change and global warming are challenging for humanity. International cooperation and the formation of joint approaches to solving global challenges are of paramount importance for sustainable development. Like many countries in the region, Ukraine threatens to increase the number of natural disasters, floods in the Carpathians, transformation southern region steppe into the desert, flooding coastal parts and a shortage of drinking water in the central and eastern regions. Thus, this study explores the international mechanism of the environmental information access as a complex multi-level system, which determines various types of international cooperation. Environmental information access is of great practical importance both for humanity as a whole and for further reformation of the legislation of individual countries in order to ensure sustainable development, as well as to improve the practical activities of civil society. The findings show the need for people`s lifestyle changes, their environmental education and work. We therefore propose the international mechanism of the environmental information access as cooperation framework which enables companies and business communities more effectively and creatively solve economic and social problems.
\end{abstract}

Keywords: Environmental information, information human rights, sustainable development, EU environmental policy, environmental human rights

\section{Introduction}

In today's realities, the study of the legal mechanism of ensuring the human right to free access to environmental information in Ukraine is of great importance.

The study of legal mechanism of ensuring the human right to free access to to environmental information has an important practical meaning for further reform of the legislation of Ukraine on ensuring the human right to have free access to environmental information, as well as to improve the practical activity of authorized entities in this area. The problem of the legal mechanism for ensuring human rights for free access to environmental information has already been raised by us (Ladychenko V., Golovko L. 2018).

It is closely linked to social issues such as Sustainable Governance (Lafferty W, 2004), global warming (Knutti R, 2013), environmental responsibility (Miao He, 2019).

\footnotetext{
${ }^{1}$ Professor and head of the Department of International Law and Comparative Law of the National University of Life and Environmental Sciences of Ukraine, Kyiv, Ukraine.

2Dean of the Faculty of Management and Law of Vinnitsa National Agrarian University (Ukraine).

${ }^{3}$ Dean the Faculty of Law of the National University of Life and Environmental Sciences of Ukraine, Professor of the Department of Administrative and Financial Law of the National University of Life and Environmental Sciences of Ukraine

${ }^{4}$ Associate Professor of the Department of Civil and Commercial Law of the National University of Life and Environmental Sciences of Ukraine
} 


\section{Statement of the Problem}

The system of legal mechanism for ensuring the human right to free access to environmental information in Ukraine is an integral part of a unified holistic system of ensuring the human right to free access to environmental information in Ukraine.

Under international law, the legal mechanism for ensuring the human right to free access to environmental information consists of the following components.

1. International UN treaties on ensuring the human right to have free access to to environmental information.

2. European mechanism to ensure the human right to access to environmental information

In particular, the Universal Declaration of Human Rights of December 10, 1948, the International Covenant on Civil and Political Rights of the United Nations of December 16, 1966, the International Covenant on Economic, Social and Cultural Rights of the United Nations of December 16, 1966, the Framework Convention of the Organization of United Nations on Climate Change of May 09, 1992.

Also an important meaning has the UNECE Convention on Access to Information, Public Participation in Decision-making and Access to Justice in Environmental Matters (Aarhus Convention) of June 25, 1998.

According to art. 3 of Aarhus Convention Each Party shall take the necessary legislative, regulatory and other measures, including measures to ensure compliance with the provisions governing the implementation of the provisions of this Convention with respect to information, public participation and its access to justice, and also appropriate measures to ensure conditions of their application, to create and maintain a clear, transparent and coordinated structure for the implementation of the provisions of the Aarhus Convention. Each Party seeks to ensure conditions that official and public authorities provide public assistance and orientation towards access to information, participation in decision-making processes and receiving access to justice in environmental matters. Each Party contributes to environmental education and public awareness of environmental issues, in particular regarding access to information, participation in decision-making and access to justice in environmental matters.

The rights and freedoms enshrined in the norms of international legislation have become a guarantee of the realization of these rights and in the information sphere. International treaties regulate various aspects of access to information, including its search, reception, and use without interference of state authorities and regardless of borders.

In art. 19 of the Universal Declaration of Human Rights it is guaranteed to every person the right on free search and receipt of information by any means irrespective of frontiers. Similar rights are enshrined in two other documents: the International Covenant on Economic, Social and Cultural Rights and the International Covenant on Civil and Political Rights. The latter directly guaranteed the right of every person on free search and receipt of information regardless of the state borders of his choice in oral, written or any other form.

In art. 2 of the United Nations Framework Convention on Climate Change of 09 May 1992 ratified by the relevant Law of Ukraine is stated that the ultimate objective of this Convention and of all related legal documents, that the Conference of the Parties may 
adopt, is to achieve in compliance with the relevant provisions of the Convention the stabilization of greenhouse gas concentrations in the atmosphere at a level that would not allow dangerous anthropogenic impacts on the climate system. Such a level should be achieved within the time frame necessary for the natural adaptation of ecosystems to climate change, which will make it possible not to jeopardize the production of food and will contribute to ensuring sustainable economic development on a sustainable basis.

An important meaning also has the Kyoto Protocol to the United Nations Framework Convention on Climate Change of December 11, 1997, ratified by the relevant Law of Ukraine of February 4, 2004.

According to art. 3 of the Kyoto Protocol, the respective Parties, individually or together, shall ensure that their aggregate anthropogenic emissions of greenhouse gases in the equivalent of carbon dioxide do not exceed the quantitative limits established for them, determined taking into account the quantitative and emission reduction commitments established therefor, from in order to reduce their total emissions of such gases by at least five percent compared to the base level of 1990 for the period of commitment from 2008 to 2012 years.

And according to art. 6 of the Kyoto Protocol in order to fulfill its obligations under article 3 of the Kyoto Protocol, any Party may transfer to any other such Party or receive from it units of emission reductions determined as a result of projects aimed at reducing anthropogenic emissions from sources or increase in removals by sinks of greenhouse gases in any sector of the economy, provided that: any such project is approved by the participating Parties; any such project involves reducing emissions from sources or increasing absorption by sinks in addition to what could have been achieved otherwise; it does not receive any emission reduction units if it does not comply with its respective obligations; receiving emission reduction units is additional to domestic measures for the fulfillment of obligations.

Consequently, the Kyoto Protocol, adopted in December 1997 in addition to the United Nations Framework Convention on Climate Change, obliges developed and transition countries to reduce or stabilize greenhouse gas emissions compared to 1990 year. For the implementation of the Kyoto Protocol, the EU and other countries that have ratified the Kyoto Protocol have developed a system of limiting industrial emissions through quotas. That is, the countries that have joined the agreement are obliged to correlate their emissions from the 1990th year - if their level exceeds the figures recorded in the 1990s, the country is obliged to compensate for the increase of emissions by purchasing the corresponding volume of quotas of those participants of the Kyoto Protocol, which have unused "reserves" of greenhouse gases.

\section{Positive Ukrainian Experience in Carbon Emission Descent}

Based on the conclusions of the scientists of the Ukrainian Hydrometeorological Institute of the National Academy of Sciences of Ukraine on the global and regional effects of climate change, it can be concluded that Ukraine is also threatened with an increase in the number of natural disasters, flooding in the Carpathians, the transformation of the southern steppes into the desert, flooding of coastal parts and acute shortage of drinking water in the central and eastern regions. 
That is why we have already emphasized the need to implement European environmental policy in Ukraine (Ladychenko, Golovko 2017).

The Kyoto Protocol is the only international treaty that forces countries to invest in policies and measures to reduce greenhouse gas emissions. With the help of flexible mechanisms (clean development and joint implementation), the projects with the volume of emissions reductions of more than 1 billion tonnes of $\mathrm{CO} 2$ were registered.

Ukraine is one of the few countries in the world that from years 1990 to 2000 sharply reduced greenhouse gas emissions due to low industrial load, and in the years to come, it did not come close to the 1990 figures. By ratifying the Kyoto Protocol in 2004, Ukraine was able to realize its unused carbon dioxide emission quotas. According to the information provided by the National Ecological Center, the state budget of Ukraine in 2009-2010 received $€ 470$ million as a result of the sale of surplus quotas under the Kyoto Protocol. At the same time, Ukraine undertook to implement greenhouse gas emission reduction projects for these funds.

Consequently, partly the Kyoto Protocol simply turned into a mechanism for generating profits from trade in quotas (business in ecology). If a country has exceeded its obligations under the Kyoto Protocol and achieved a greater reduction in emissions, it could sell them to another country. In reality, countries with quotas (most notably in Russia, Ukraine, Belarus, Poland, Romania) did not achieve them due to the deliberate policy of governments, but at the expense of the recession and restructuring of the economy after 1990. Such quotas are also referred to as "hot air". Public organizations are opposed to the sale of "hot air", because at the global level, this will not lead to additional reductions in greenhouse gas emissions.

The main problems of international emissions trading mechanism is the lack of any rules at the Kyoto Protocol as for the transparent use of funds, and especially their target spend. The rules are dictated by the buyer of the quotas. In an agreement with Japan, it was stated that funds could be used only for projects aimed at reducing greenhouse gas emissions. Although the selection process projects for green investment scheme must be transparent, a number of requests from environmental organizations, which funds projects went and planned reductions obtained repeatedly, received the answer "confidential information". The process of adopting state procedures for the distribution of funds was not transparent; a number of resolutions had never been made public.

It is important to reduce the impact of carbon dioxide emissions in the EU (Rootzén, J., Kjärstad, J. Johnsson, F. 2011,) and the Balkan countries (Shkurti 2019). As for Ukraine, under contracts for the sale of units (parts) of the established amount of greenhouse gas emissions with the Japanese party, 707 projects of target environmental ("green") investments were approved for a total amount of $\$ 575000$. Of these, in October 2013, 162 projects in the social sphere were additionally approved by the Japanese side. They were carried out during the period of 2014-2015 598 projects on overhaul (heat treatment) of social facilities (insulation of facades and roofs, replacement of windows and doors), which are implemented mainly in educational and health institutions in almost all regions of Ukraine. 27 projects on technical re-equipment of fixtures based on incandescent lamps on LED-based fixtures. 75 projects for the replacement of lifts in residential buildings and social facilities. And also such large-scale projects using the Japanese technologies: 
- the project on the construction of wastewater treatment facilities for the mine water of mine nd. a. P. Voikova, Sverdlovsk city, Lugansk region;

- a project for the reconstruction of the boiler room of the block №165 with the introduction of heat pumps, Dzerzhinsk city, Donetsk region;

- a project for the comprehensive modernization of carloads with the introduction of asynchronous traction drive at Municipal Enterprise "Kyivs'kyi metropolitan";

- two projects for technical re-equipment (replacement of rolling stock of existing patrol cars) by cars with a hybrid power plant at the Ministry of Internal Affairs of Ukraine;

- a project for the reconstruction of the district heating system "Sonyachnyy" and "Budivelnyk" microdistrict in Horlivka city, Donetsk region. (first line).

One of the large-scale projects is the replacement of old cars of the Ministry of Internal Affairs of Ukraine with the new hybrid cars Toyota Prius. Such cars today can be seen on the streets of cities and highways throughout Ukraine.

The specifics of the agreements related to the limitation of anthropogenic impact on the climate system, and, first of all - the Kyoto Protocol, the regional instrument complementary to it, and the draft post-Kyoto documents, are: along with the commitments on greenhouse gas emission limitations, funds that promote the concentration and directing of financial resources for investment needs in increasing the environmental efficiency of production and living areas.

The Okinawan Charter of the Global Information Society, dated July 22, 2000, was the conceptual international document in the modern conditions of the construction and development of the information society and the provision of rights of the subjects of information relations. This international treaty is important in the context of the rapid development of information and communication technologies, and a well-developed information society will allow people to make greater use of their potential and realize their direction, including in the information sphere. It states that information and communication technologies are one of the most important factors influencing the formation of a society of the XXI century. Their revolutionary influence concerns the way people live, their education and work, as well as the interaction between government and civil society. Information and communication technologies are rapidly becoming a vital stimulus for the development of the world economy, and they also enable individuals, firms and communities engaged in entrepreneurial activity to more effectively and creatively solve economic and social problems.

The Okinawan Charter is an appeal to all public and private sectors to eliminate the international divide in the information sphere, and one of the tasks of the international community determines the development of information networks that provide fast, reliable, secure and economical access through competitive market conditions and relevant innovations to network technologies, effective partnership between the public and private sectors in the field of information technology use, etc.

A number of important provisions on the guarantee of the right to access environmental information are enshrined in the Convention on Access to Information, which guarantees public participation in decision-making or access to justice in environmental matters (the Aarhus Convention). An analysis of the provisions of the Convention indicates that an important role is played by the ability to receive complete and objective information on the state of the environment in a timely manner. Parties to this 
Convention, confirming the need to protect and save the environment and improve its state, recognize the right of citizens to have access to information about the state of the environment, public awareness of environmental problems, etc. In art. 1 of the Aarhus Convention is stipulated that, in order to promote the protection of the right of everyone to present and future generations to live in an environment conducive to their health and well-being, each of the Parties guarantees the right to access information, public participation in the decision-making process and access to justice in matters relating to the environment in accordance with the provisions of this Convention. Issues of legal guarantees of access to environmental information are regulated in art. 4-5 of the Convention, in particular: guarantees of access to state bodies with information requests, maximum deadlines for receiving responses to such requests, transparency of environmental information, etc.

The UN has announced current century is the century of biotechnology. This is due to the fact that in recent years there have been some achievements in the field of genetic engineering, which in many countries have become a priority.

Every year at UN level, June 5 is celebrated as World Environment Day, which is one of the main ways for the United Nations to attract global public attention to environmental issues, and also to stimulate political interest and corresponding actions.

\section{EU Mechanism to Ensure the Human Right to Access to Environmental Information}

International treaties of the Council of Europe on ensuring the human right to free access to environmental information. In particular, The European Convention on Human Rights of November 4, 1950, the Pan-European Strategy for the Conservation of Biological and Landscape Diversity of October 25, 1995.

At the international level, the issue of access to information was first addressed to the Council of Europe in 1976 at the Colloquium on "Freedom of Information - the Obligation of Public Authorities to Provide Access to Information." The result of this discussion was the Recommendation of the Parliamentary Assembly of the Council of Europe No 854 (1979) "On Public Access to State Documentation and Freedom of Information", adopted in 1979, according to which Member States were requested to introduce a system of freedom of information that should provide citizens:

- access to public files;

- the right to seek and receive information from state institutions and agencies;

- the right to review and correct personal files;

- the right to privacy;

- the right of quick review by the courts of these issues.

Such a recommendation was due to the fact that public authorities began to generate a large amount of information that is at their sole disposal, while such a system of freedom of information was intended to provide an opportunity for corruption scrutiny and public money laundering. That is, taxpayers, as filling state budgets, have the right to know how public funds are used, and therefore to control bodies of state power for abuse of their powers.

Cooperation between Ukraine and the European Union in the environmental field was 
considered by modern scholars (Gulac, Dubchak, Iarmolenko, Yanchuk 2019).

A number of important provisions extending international regulatory safeguards for access to information are contained in Recommendation No. R (81) 19 of the Committee of Ministers to member states on the access to information held by public authorities, which lays down the fundamental principles the right to receive information from these authorities. The Council of Europe encourages Member States to follow, in their legislation and practice, the principles attached to this recommendation. The main object of the recommendations is the principle of the right of everyone within the jurisdiction of a Member State to receive, at the request of information, available to public authorities, in addition to legislative and judicial authorities. The principle of the prohibition of denial of access to information on the grounds that the person making the request is not of particular interest in this issue formed on the basis of public assistance in matters of public life. The equality of the parties implies the possibility of access to information to any person and the exclusion of the principle of discrimination in information relations. Equally important are the principles of observing the reasonable timing of the consideration of the information request, the possibility of challenging the refusal to respond to it, the right to choose effective and appropriate means of access to information.

Similar principles and approaches have become the basis for Member States in shaping legislation and practices to ensure everyone's right to access information, as well as enshrined in other international instruments that define the international legal framework for access to information. Such principles are the basis for the formation of national information legislation, since each state party to an international treaty undertakes appropriate obligations. At the same time, it is emphasized that when applying the above principles, it is necessary to take into account the restrictions and prohibitions that are necessary in a democratic society to protect the legitimate interests of society and to protect private life and other legitimate private interests. Such principles were based on the understanding that for a democratic society there is an important legal opportunity for the public to access information on socially important issues that will enhance public confidence in public administration.

The adoption in 2008 of the Council of Europe Convention on Access to Official Documents became the final recognition of the right to access public information at the international level. This is the first international instrument of compulsory action, which establishes a mechanism for protecting the right to access information. The Convention "On Access to Official Documents" provides the right to access to official documents held by public authorities to individuals and legal entities, but taking into account restrictions aimed at protecting statutory interests. In addition, the convention lists the bodies that are public. There is no provision for the minimum and maximum time limits for providing information, but is left to the discretion of each state.

Recommendation 14 (1995) of the Congress of Local and Regional Authorities of the Council of Europe on the European Charter for Mountainous Regions, Recommendation 75 (2000) on the draft of European Framework Convention for Mountainous Regions, Recommendation 130 (2003) on the European Charter for Mountains; Recommendation 1638 (2005) on the sustainable development of mountain regions is of great importance in ensuring the right of citizens to have free access to 
environmental information.

\section{Conclusions}

Based on the foregoing, the following conclusions can be made. The regulatory system of the administrative and legal mechanism for ensuring the human right to free access to environmental information is essential for the development of an information society in a democratic and law-governed state.

Proper implementation and administrative and legal provision of the human right to free access to environmental information are an integral requirement of a democratic and law-governed state, a guarantee of civil society development, an appropriate level of public confidence in public authorities. The lack of proper implementation of such a right of citizens and its inadequate administrative and legal provision is inadmissible under the conditions of a legal and democratic state, and during the Chornobyl catastrophe - the disasters of a planetary scale on April 26, 1986, led to the terrible consequences, as mentioned above.

Consequently, this subsection describes the problems of the normative system of the administrative and legal mechanism for ensuring the human right to free access to environmental information in Ukraine under international law.

\section{References}

Access by the public to government records and freedom of information: PA CE Recommendation 854 (1979) from 1 February 1979. Retrieved from: http://assembly.coe.int/nw/xml/XRef/XrefXML2HTML-en.asp?fileid= 14888\&lang=en

Boyko, I. Guaranteeing the right of citizens to free access to information on the quality of food products: the administrative-legal aspect. Bulletin of the Academy of Legal Sciences of Ukraine, No.1, 187-194.

Collins M, Knutti R, Arblaster J, et al. (2013). Climate Change 2013: The Physical Science Basis. Cambridge University Press, 1029-1136.

Council of Europe Convention on Access to Official Documents of 2008. Retrieved from: http://stop-xfiles-ua.org/council-of-europe-convention-on-access-to-official-documents/

Gulac, O., Dubchak, L., Iarmolenko, I., Yanchuk, J. (2019). Cooperation of Ukraine and the European Union in the ecological sector: directions and prospects. European Journal of Sustainable Development, Volume 8, No. 1, 22-30.

Kyoto Protocol to the United Nations Framework Convention on Climate Change of December 11, 1997. Retrieved from: http://zakon5.rada. gov.ua/laws/show/995 801

Ladychenko V., Golovko L. (2018). The Right to Access to Environmental Information in Ukraine and the EU. European Journal of Sustainable Development, Volume 7, No. 3, 455-459.

Ladychenko, V., Yara, O., Golovko, L., Serediuk, V. (2019) Groundwater Management in Ukraine and the EU. European Journal of Sustainable Development Volume 8 No. 1, 31-39.

Ladychenko, V., Golovko, L. (2017). Implementation of European Environmental Policy in Ukraine: Problems and Prospects. European Journal of Sustainable Development, Volume 6, No. 3, 333-339

Miao, He. (2019). Sustainable Development through the Right to Access to Justice in Environmental Matters in China. Sustainability, 11(3), 900.

On Ratification of the United Nations Framework Convention on Climate Change: Law of Ukraine dated October 29, 1996 // Bulletin of the Verkhovna Rada of Ukraine - 1996. № 50. - p. 277.

Pan-European Strategy for the Conservation of Biological and Landscape Diversity of the Council of Europe of October 25, 1995. Retrieved from: http://zakon3.rada.gov.ua/laws/show/994 711

Recommendation 130 (2003) on the European Charter On the Protection of Mountains of May 22, 2003. Retrieved from: https://wcd.coe.int/ViewDoc.jsp?id=935075 
Recommendation 14 (1995) on The European Charter of Mountain Regions The Congress of Local and Regional Authorities of Europe from 31 May 1995. Retrieved from: https://wcd.coe.int/ViewDoc.jsp? id=825443

Recommendation 75 (2000) on the draft European framework convention on mountain regions of May 24, 2000. Retrieved from: https://wcd.coe.int/ViewDoc.jsp?id=928801

Recommendation No. R (81) 19 of the Committee of Ministers to member states on the access to information held by public authorities. Retrieved from: https://www.coe.int/en/web/freedomexpression/committee-of-ministers-adopted-texts/-

/asset_publisher/aDXmrol0vvsU/content/recommendation-no-r-81-19-of-the-committee-ofministers-to-member-states-on-the-access-to-information-held-by-publicauthorities?inheritRedirect $=$ false

Rootzén, J., Kjärstad, J., Johnsson, F. (2011). Prospects for CO2 capture in European industry. Management of Environmental Quality: An International Journal, Vol. 22, No. 1,18-32.

Shkurti, A. (2019) Analysis of the Western Balkans power market prices within the entso-e framework. European Journal of Sustainable Development, Volume 8, No. 1, 229-236

Sustainable development of mountain regions - Parliamentary Assembly Recommendation 1638 (2003) from 28 September 2005. Retrieved from: https://wcd.coe.int/ViewDoc.jsp?Ref=CM/AS(2005) Rec1638\&Language $=$ lanEnglish $\&$ Ver $=$ prov\&Site $=C O E \& B a c k$ ColorInternet $=$ DBDCF $2 \& B$ ackC olorIntranet $=$ FDC $864 \&$ BackColorLogged $=$ FDC864

The Okinawan Charter of the Global Information Society of 22 July 2000. Retrieved from: http://zakon5.rada. gov.ua/laws/show/998 163

United Nations Climate Change: Law of Ukraine dated February 4 // Bulletin of the Verkhovna Rada of Ukraine. - 2004. - No. 19. - p. 261.

United Nations Framework Convention on Climate Change of 09 May 1992. Retrieved from: http://zakon3.rada.gov.ua/laws/show/995 044

What is the Kyoto Protocol and its role in preserving our planet? Retrieved from: http://eco.sii. org.ua/ щоявАяс-собою-кіотський-протокол-і-йо/

William M. (2004). Lafferty Governance for Sustainable Development: The Challenge of Adapting Form to Function. -400 p.

World Environment Day. Retrieved from: http://www.unepcom.ru/unep/wed-m.html

Yara, O., Uliutina, O., Golovko, L., Andrushchenko, L. (2018). The EU Water Framework Directive: Challenges and Prospects for Implementation in Ukraine. European Journal of Sustainable development, Volume 7, No. 2, 175-182 